\title{
Efficient Water Management through Drip Irrigation in Wheat
}

\author{
M. S. Dabhi", A. S. Patel, K. J. Vihol, K. I. Patel, A. K. Patel and S. I. Patel \\ Wheat Research Station, S. D. Agricultural University, Vijapur-384 570, India \\ *Corresponding author
}

\section{Keywords}

Drip irrigation, Irrigation scheduling, Water use efficiency, water saving

\section{Article Info}

Accepted: 26 July 2020 Available Online: 10 August 2020

\begin{abstract}
A B S T R A C T
A field experiment was conducted at wheat research station, SDAU, Vijapur farm during rabi 2016-17, 2017-18 \& 2018-19 to evaluate the "Efficient water management through drip irrigation in wheat". The trial comprised of seven irrigation treatments with four replications designed in Randomized Block Design. The results revealed that significantly higher grain yield (54.10 q/ha) was recorded through drip scheduled at $100 \% \mathrm{PE}$ and it was statistically at par with the treatments, $1.2 \mathrm{IW} / \mathrm{CPE}$ ratio $(53.50 \mathrm{q} / \mathrm{ha}), 80 \% \mathrm{PE}(51.10$ $\mathrm{q} / \mathrm{ha})$, and 1.0 IW/CPE ratio (49.80 q/ha). Significantly higher biomass yield was recorded under 1.2 IW/CPE ratio (114.60 q/ha) and it was at par with treatments, $100 \% \mathrm{PE}(109.30$ q/ha), 80\% PE (111.60 q/ha), and 1.0 IW/CPE ratio (107.10 q/ha). The yield attributing characters like, spikes per sq. meter, 1000 grain weight $(\mathrm{g})$, grains per spike \& plant height had reflected significant effect. Significantly higher number of spikes per $\mathrm{m}^{2}$ (411 nos.) was recorded under drip irrigation scheduled at $100 \% \mathrm{PE}$ which was at par with 1.2 IW/CPE ratio (378 nos.) while significantly higher no. of grains per spike (50.2 Nos.) was recorded under drip irrigation scheduled at $100 \%$ PE. Due to significant effect of treatments, higher test weight was registered under drip irrigation scheduled at 1.0 IW/CPE ratio $(47.7 \mathrm{~g})$. The highest water consumption $(420 \mathrm{~mm})$ was recorded under check basin treatment \& 1.2 IW/CPE ratio, while the highest water saving $(55.55 \%)$ was registered under drip irrigation scheduled at $60 \% \mathrm{PE}$.
\end{abstract}

\section{Introduction}

Wheat [Triticum aestivum (L.) emend. Fiori \& Paol.] is the most important staple food crop of the world and emerged as the backbone of India's food security. It is grown all over the world for its wider adaptability and high nutritive value. It is an important winter cereal contributing about $38 \%$ of the total food grain production in India. Wheat straw is an important source of fodder for a large animal population in India. In India, wheat is the second most important cereal crop after rice covering an area of 30.79 million hectares. Total annual production of wheat in India is 98.51 million tonnes with the productivity of 3.20 tonnes per hectare during 2017-18 (Anon. 2017-18). India is the second largest wheat producer (approximately 12 per cent of world's wheat production) and consumer after China. In Gujarat, wheat is an important rabi crop and is grown almost 
throughout the state with 1.05 million hectares area under cultivation, total production of wheat was 3.05 million tonnes with an average yield of 2.89 tonnes per hectare during 2017-18 (Anon. 2017-18).

Wheat is a high water consuming crop. Water is one of the important and costlier inputs in modern agriculture. It is well established fact that water stress reduces wheat grain yield. In general, water requirement of semi-dwarf wheat varieties is about $45 \mathrm{~cm}$ in the form of 4-6 irrigations with a depth of 4-7 cm (Sharma, 2005). In North Gujarat, underground water is the main source of irrigation water which is very costlier and very poor in quality. Due to, Narmada canal, wheat growing area under canal irrigation also have to increase year by year. But, due to higher frequencies as well as over irrigation of underground or canal water, the soil health deteriorates which reflects to decreasing crop productivity and its quality. Wheat production and its quality also affect due to water stress. Therefore, there is a need of efficient utilization of irrigation water through appropriate irrigation method and it's scheduling to achieve higher water and crop productivity. Drip irrigation has proved its superiority in widely spaced crops. Therefore, experiment was planned to check the possibilities of drip irrigation method for efficient water management in closed space wheat crop.

\section{Materials and Methods}

A field experiment was conducted during the Rabi, 2016-17, 17-18 \& 18-19. The experimental soil was sandy loam with $\mathrm{pH}$ 7.79, electrical conductivity (EC) $0.36 \mathrm{dS} \mathrm{m}^{-1}$, organic carbon $0.33 \%$ with available $\mathrm{N}(162$ $\mathrm{Kg} / \mathrm{ha}), \mathrm{P}_{2} \mathrm{O}_{5}(37.72 \mathrm{Kg} / \mathrm{ha})$ and $\mathrm{K}_{2} \mathrm{O}(289$ $\mathrm{Kg} / \mathrm{ha}$ ). The experiment was laid out in Randomized Block Design with 7 irrigation treatments in 4 replications. The treatment consists of six irrigation schedules of drip irrigation with one check basin, i.e. $\mathrm{T}_{1}-100 \%$ PE, $\mathrm{T}_{2}-80 \%$ PE, $\mathrm{T}_{3}-60 \% \mathrm{PE}, \mathrm{T}_{4}-1.2 \mathrm{IW} / \mathrm{CPE}$ (41.6 CPE), $\mathrm{T}_{5}-1.0 \mathrm{IW} / \mathrm{CPE}$ (50 CPE), $\mathrm{T}_{6}-0.8$ IW/CPE (62.5 CPE) and $\mathrm{T}_{7-} 60 \mathrm{~mm}$ irrigation depth in check basin method. Application of water was given according to the treatments in which water quantity on PE basis treatment was given on the basis of value of CPE (Cumulative Pan Evaporimeter) of every three days interval and water was applied according to \% PE. In $100 \%$ PE treatment full quantity of water was apply in $\mathrm{mm}$ equal to $\mathrm{mm}$ of water evaporate from CPE (Cumulative Pan Evaporimeter). Similarly in $80 \%$ PE \& $60 \%$ PE treatment only $80 \%$ and $60 \%$ of water in $\mathrm{mm}$ was given to the total water evaporated from CPE (Cumulative Pan Evaporimeter), respectively. In IW/CPE basis irrigation scheduling, water was applied on IW/CPE ratio basis. In every IW/CPE ratio, $50 \mathrm{~mm}$ depth of water was given. In 1.2 IW/CPE ratio drip scheduling, water of $50 \mathrm{~mm}$ depth was given when CPE value reached at 41.6 $\mathrm{mm}$. Similarly in $1.0 \& 0.8 \mathrm{IW} / \mathrm{CPE}$ ratio, water of $50 \mathrm{~mm}$ was given when CPE value reached at $50 \mathrm{~mm}$ and $62.5 \mathrm{~mm}$, respectively.

The daily pan evaporation values were measured with the help of USWB class 'A' open pan evaporimeter installed in the experimental field. While in check basin method crop was irrigated with $60 \mathrm{~mm}$ depth of water at every critical stage. All other cultivation practices were adopted as per recommendations. There was no rainfall during the crop season. Wheat variety GW322 sown at $20.0 \mathrm{~cm}$ spacing between two rows@125 kg/ha seed rate and crop was fertilized by recommended dose i.e. 120-60$40 \mathrm{~kg} / \mathrm{ha} \mathrm{N}-\mathrm{P}_{2} \mathrm{O}_{5}-\mathrm{K}_{2} \mathrm{O}$. Water use efficiency (WUE) was calculated by dividing grain yield with total irrigation water (Cochran and cox, 1967). The values off " $F$ " was worked out and compared with the values of table $F$ at 5 per cent level of significance. The value of S.Em. 
\pm , C.D. and C.V. \% were also calculated (Cochran and cox, 1967).

\section{Results and Discussion}

\section{Grain yield (q/ha)}

The data presented in Table 1 revealed that grain yield of wheat crop was significantly influenced under different water management treatments. Significantly higher grain yield $(54.10 \mathrm{q} / \mathrm{ha})$ was recorded through drip scheduled at $100 \% \mathrm{PE}$, however, it was statistically at par with the treatments, 1.2 IW/CPE ratio (53.50 q/ha), 80\% PE (51.10 $\mathrm{q} / \mathrm{ha})$, and 1.0 IW/CPE ratio (49.80 q/ha). The significantly lower grain yield $(40.4 \mathrm{q} / \mathrm{ha})$ was recorded under flood irrigation $\left(\mathrm{T}_{7}\right)$ and it was statistically at par $0.8 \mathrm{IW} / \mathrm{CPE}$ (41.5 q/ha).

Higher grain yield was recorded due to the cumulative effect of growth and yield attributes such as effective tillers $\mathrm{m}^{-2}$, no. of grains per spike and 1000 grain weight. It was also due to sufficient moisture regime in the soil profile under drip irrigation which increases the availability of plant nutrients reflected in to more dry matter production. These results are in conformity with the results of Rahman (2009), Kharrou et al., (2011) Abdelaraouf and Habbasha (2014), Chen et al., (2015), Chouhan et al., (2015) ${ }^{\text {, }}$, Chouhan et al., (2015) and Dholiya et al., (2017).

\section{Biomass yield (q/ha)}

The result presented in Table 1 revealed that the effect of different water management treatments was significant on biomass yield of wheat. Significantly higher biomass yield (114.6 q/ha) was recorded under 1.2 IW/CPE ratio and it was statistically at par with the treatments, $80 \%$ PE (111.60 q/ha), 100\% PE $(109.30 \mathrm{q} / \mathrm{ha})$ and 1.0 IW/CPE ratio (107.10 $\mathrm{q} / \mathrm{ha})$. The lowest biomass yield (91.5 q/ha) was recorded under at $0.8 \mathrm{IW}$ : CPE. Higher biomass yield was recorded under the 1.2 IW/CPE ratio due to the cumulative effect of better vegetative growth and yield attributes. These findings are in agreement with the results of Rahman (2009), Kharrou et al., (2011), Abdelraouf and Habbasha (2014) Chouhan et al., (2015) ${ }^{\mathrm{b}}$ and Dholiya et al., (2017).

\section{0 grain weight $(\mathrm{g})$}

The data presented in Table 1 showed that different water management treatments had significant influence on 1000 grains weight (g). Significantly the highest 1000 grains weight $(47.7 \mathrm{~g})$ was registered under 1.0 IW/CPE $\left(\mathrm{T}_{5}\right)$. However, it remains statistically at par with all treatments except flood irrigation $\left(\mathrm{T}_{7}\right)$. Lower 1000 grain weight was recorded under flood irrigation $(43.4 \mathrm{~g})$.

Under different water management treatments the crop was irrigated with adequate quantity of water at narrow intervals which provide sufficient soil moisture to the crop resulted into higher photosynthesis at grain filling and development stages and ultimately reflected in higher 1000 grain weight These results are in line with Rahman (2009), Kharrou et al., (2011), Arafa et al., (2009) and Chouhan et al., (2015) .

\section{Spikes per $\mathbf{m}^{2}$}

The data presented in Table 1 indicated that different water management treatments exerted significant influence on number of spikes per square meter. Significantly higher number of spikes per $\mathrm{m}^{2}$ (411 Nos.) was recorded under irrigation scheduled at $100 \% \mathrm{PE}$ which was at par with 1.2 IW/CPE ratio (378 Nos.). Lower number of ear heads per square metre was recorded under $0.8 \mathrm{IW} / \mathrm{CPE}\left(\mathrm{T}_{6}\right)$ which was statistically at par with $60 \% \mathrm{PE}\left(\mathrm{T}_{3}\right), 1.0$ IW/CPE $\left(T_{5}\right)$ and flood irrigation $\left(\mathrm{T}_{7}\right)$. 
Table.1 Yield and yield attributes of wheat as influenced by different treatments (Pooled data of three years)

\begin{tabular}{|c|c|c|c|c|c|c|c|c|c|c|}
\hline Treatments & $\begin{array}{c}\text { Grain } \\
\text { yield } \\
\text { (q/ha) }\end{array}$ & $\begin{array}{c}\text { Biomass } \\
\text { yield } \\
\text { (q/ha) }\end{array}$ & $\begin{array}{l}1000 \\
\text { grain wt. } \\
(\text { gm) }\end{array}$ & $\begin{array}{c}\text { Spike } \\
\text { /squar } \\
\text { e m }^{2}\end{array}$ & $\begin{array}{c}\text { No. } \\
\text { grains / } \\
\text { spike }\end{array}$ & $\begin{array}{c}\text { Length of } \\
\text { spike } \\
\text { (cm) }\end{array}$ & $\begin{array}{l}\text { Plant } \\
\text { height } \\
(\mathrm{cm})\end{array}$ & $\begin{array}{c}\text { Water } \\
\text { used } \\
(\mathrm{mm})\end{array}$ & $\begin{array}{c}\% \\
\text { Water } \\
\text { saving }\end{array}$ & $\begin{array}{c}\text { WUE } \\
(\mathrm{kg} / \mathrm{ha} / \mathrm{mm})\end{array}$ \\
\hline $\mathrm{T}_{1}: 100 \% \mathrm{PE}$ & 54.1 & 109.3 & 44.6 & 411 & 50.2 & 8.67 & 87.77 & 370 & 13.51 & 14.64 \\
\hline $\mathrm{T}_{2}: \mathbf{8 0} \% \mathrm{PE}$ & 51.1 & 111.6 & 46.9 & 366 & 48.2 & 8.79 & 86.89 & 320 & 31.25 & 15.99 \\
\hline $\mathrm{T}_{3}: 60 \% \mathrm{PE}$ & 45.5 & 99.6 & 46.2 & 351 & 48.3 & 9.08 & 87.39 & 270 & 55.55 & 16.88 \\
\hline $\mathrm{T}_{4}: 1.2 \mathrm{IW} / \mathrm{CPE}$ & 53.5 & 114.6 & 47.4 & 378 & 47.8 & 8.81 & 87.31 & 420 & 0.00 & 12.73 \\
\hline $\mathrm{T}_{5}: 1.0 \mathrm{IW} / \mathrm{CPE}$ & 49.8 & 107.1 & 47.7 & 363 & 49.2 & 8.77 & 84.43 & 370 & 13.51 & 13.46 \\
\hline $\mathrm{T}_{6}: 0.8 \mathrm{IW} / \mathrm{CPE}$ & 41.5 & 91.5 & 47.3 & 326 & 50.0 & 8.44 & 79.32 & 320 & 31.25 & 12.97 \\
\hline $\mathbf{T}_{7}:$ Flood irrigation & 40.4 & 100.1 & 43.4 & 330 & 43.8 & 8.63 & 85.12 & 420 & 0.00 & 8.87 \\
\hline S.Em. \pm & 2.67 & 4.1 & 1.1 & 12.8 & 1.7 & 0.19 & 1.87 & - & - & - \\
\hline CD (0.05) & 6.18 & 12.5 & 3.2 & 39.3 & 5.3 & 0.59 & 5.76 & - & - & - \\
\hline CV\% & 8.69 & 7.8 & 4.3 & 6.5 & 6.2 & 3.79 & 2.88 & - & - & - \\
\hline
\end{tabular}

Table.2 Economics of wheat crop as influenced by different water management treatments (Pooled basis)

\begin{tabular}{|c|c|c|c|c|}
\hline $\begin{array}{c}\text { Water management } \\
\text { treatments }\end{array}$ & $\begin{array}{c}\text { Cost of Cultivation } \\
\text { (₹/ha) }\end{array}$ & $\begin{array}{c}\text { Gross realization } \\
\text { (₹/ha) }\end{array}$ & $\begin{array}{l}\text { Net Realization } \\
\text { (₹/ha) }\end{array}$ & $\begin{array}{l}\mathrm{B}: \mathrm{C} \\
\text { ratio }\end{array}$ \\
\hline $\mathrm{T}_{1}: 100 \% \mathrm{PE}$ & 44448 & 113830 & 69382 & 2.56 \\
\hline $\mathrm{T}_{2}: \mathbf{8 0 \%} \mathrm{PE}$ & 44008 & 109190 & 65182 & 2.48 \\
\hline $\mathrm{T}_{3}: 60 \% \mathrm{PE}$ & 43568 & 97270 & 53702 & 2.23 \\
\hline $\mathrm{T}_{4}: 1.2 \mathrm{IW} / \mathrm{CPE}$ & 38171 & 113870 & 75699 & 2.98 \\
\hline $\mathrm{T}_{5}: 1.0 \mathrm{IW} / \mathrm{CPE}$ & 37731 & 106080 & 68349 & 2.81 \\
\hline $\mathrm{T}_{6}: 0.8 \mathrm{IW} / \mathrm{CPE}$ & 37291 & 88850 & 51559 & 2.38 \\
\hline $\mathbf{T}_{7}:$ Flood irrigation & 39265 & 88700 & 49435 & 2.26 \\
\hline
\end{tabular}

\begin{tabular}{|l|l|l|}
\hline Selling Price (₹/qt) & \multicolumn{2}{l|}{} \\
\hline Wheat grain & $:$ & $1900 / q t$ \\
\hline Wheat fodder & $:$ & $200 / q t$ \\
\hline
\end{tabular}


No. of spikes per sq. metre might be increase due to frequent and adequate supply of irrigation water under drip irrigation which creates favorable condition in root zone to supply more nitrogen and phosphorus which increased cell turgidity.

The present findings are in closely related with the results of Chouhan et al., (2015) ${ }^{\mathrm{b}}$ and Dholiya et al., (2017).

\section{Grains/spike}

The data presented in Table 1 showed that different water management treatments exerted significant influence on number of grains per spike. Higher number of grains per spike (50.2 no.) was registered under $100 \%$ $\mathrm{PE}\left(\mathrm{T}_{1}\right)$ which was statistically at par with rest of all the irrigation scheduling treatments except flood irrigation $\left(\mathrm{T}_{7}\right)$.

\section{Length of spike (cm)}

The data presented in Table 1 revealed that effect of different water management treatments on length of spike was found significant. Significantly higher length of spike was registered under $60 \%$ PE $(9.08 \mathrm{~cm})$ $\left(\mathrm{T}_{3}\right)$ and it remains at par with all the irrigation management treatments except 0.8 IW/CPE $\left(\mathrm{T}_{6}\right)$ while lower length of spike was registered under $0.8 \mathrm{IW} / \mathrm{CPE}$.

\section{Plant height (cm)}

The data presented in Table 1 revealed that plant height was significantly affected under different water management treatments. Significantly higher plant height observed under $100 \%$ PE $(87.77 \mathrm{~cm})\left(\mathrm{T}_{1}\right)$ and it remains at par with all the irrigation management treatments except $0.8 \mathrm{IW} / \mathrm{CPE}$ $\left(\mathrm{T}_{6}\right)$. Significantly lower plant height (79.32 $\mathrm{cm})$ was recorded under 0.8 IW/CPE $\left(\mathrm{T}_{6}\right)$.

\section{Water used (mm)}

The data presented in Table 1 indicated water used under different treatments. The maximum water $(420 \mathrm{~mm})$ was applied under flood irrigation $\left(\mathrm{T}_{7}\right)$ and $1.2 \mathrm{IW} / \mathrm{CPE}\left(\mathrm{T}_{4}\right)$. The lowest water $(270 \mathrm{~mm})$ was applied under $60 \% \mathrm{PE}\left(\mathrm{T}_{3}\right)$.

\section{$\%$ Water saving}

The data presented in Table 1 indicated that percent water saving under different treatments. Among different irrigation treatments, maximum water saving $(55.55 \%)$ was observed under drip irrigation scheduling at $60 \% \mathrm{PE}(270 \mathrm{~mm})$ as compare to check basin irrigation $(420 \mathrm{~mm})$ brought $64.28 \%$ more area under irrigation

\section{Water use efficiency $(\mathrm{kg} / \mathrm{ha} / \mathrm{mm})$}

The efficient water utilization by wheat crop was observed under drip irrigation scheduling as compare to the check basin irrigation method. The highest WUE was recorded under drip irrigation scheduling at $60 \% \mathrm{PE}$ $(16.88 \mathrm{~kg} / \mathrm{ha} / \mathrm{mm})$ which followed by $80 \% \mathrm{PE}$ (15.99 kg/ha/mm), $100 \% \quad$ PE (14.64 $\mathrm{kg} / \mathrm{ha} / \mathrm{mm})$ and $1.0 \quad$ IW/CPE $\quad(13.46$ $\mathrm{kg} / \mathrm{ha} / \mathrm{mm}$ ). The reason was higher grain yield achieved in proportion to the quantity of water used. Similar results were also reported by Abdelaraouf and Habbasha (2014), Chouhan et al., (2015), Chouhan et al., (2015) and Ignatius et al., (2013).

\section{Economics}

The data presented in Table 2 showed that the highest gross realization (₹1,13,870/-) and net realization (₹75,699/-) was achieved under 1.2 IW/CPE $\left(\mathrm{T}_{4}\right)$ with $2.98 \mathrm{BCR}$ followed by $100 \% \mathrm{PE}\left(\mathrm{T}_{1}\right)$ achieving gross realization ( $₹ 1,13,830 /-)$ and net realization (₹69,382/-) with 2.56 BCR while the lowest 
gross realization (₹88,700/-) and net realization (₹49,435/-) with 2.26 BCR was achieved under flood irrigation $\left(\mathrm{T}_{7}\right)$.

In conclusion a field experiment was conducted to achieve efficient water management through drip irrigation method. Drip irrigation increased the growth and yield attributes as well as grain and biomass yield of wheat. The overall finding of present investigation indicated that for getting higher yield $(51.10 \mathrm{q} / \mathrm{ha})$ with $37.25 \%$ water saving wheat crop should be irrigated at $80 \%$ PE. Based on IW/CPE ratio wheat crop should be irrigated with drip at 1.2 IW/CPE by arranging laterals $80 \mathrm{~cm}$ apart with $4 \mathrm{LPH}$ drippers at $40 \mathrm{~cm}$ apart after plant establishment. Total six irrigations each of 50 $\mathrm{mm}$ depth should be applied after plant establishment.

\section{References}

Anonymous, (2017-18). http://www.agricoop. nic.in.

Abdelaraouf, R. E. and Habbasha, S. F. 2014. Wheat production in the arid regions by using drip irrigation system. International Journal of Advanced Research 2(3), 84-96.

Arafa YE, Essam AW, Hazem EM. 2009. Maximizing water use efficiency in wheat yields based on drip irrigation systems. Australian Journal of Basic and Applied Sciences. 2009; 3(2): 790-6.

Chen, R., Cheng, W., Liao, J., Fan, H., Zheng. Z. and Ma, F. 2015. Lateral spacing in drip-irrigated wheat: The effect on soil moisture, yield, and water use efficiency. Field Crops Research 179: 52-62.

Chouhan, S. S., Awasthi, M. K. and Nema, R.
K. $2015^{\mathrm{a}}$. Studies on water productivity and yield responses of wheat based on drip irrigation systems in clay loam soil. Indian Journal of Science and Technology 8(7), 650-654.

Chouhan, S. S., Awasthi, M. K., Nema, R. K. and Koshita, L. D. 2015 . Effect of dripper spacing on yield and water productivity of wheat under drip irrigation. Research on Crops 16(3): 456-464.

Cochran WG and Cox GM. Experimental Designs, John Willey and Sons. Inc. New York. 1967, 546-568.

Dholiya, S.N., Bhanvadia, A.S. and Barkha 2017. Yield, water use efficiency and economics of wheat (Triticum aestivum L.) as influenced by different lateral spacing with drip irrigation and nitrogen levels.

Journal of Pharmacognosy and Phytochemistry 6(5): 666-668.

Ignatius M, Imtiyaz M, Kumar JL. 2013. Response of cabbage (Brassica Oleracea) under variable irrigation and lateral spacing. Research Journal of Engineering Sciences. 2(10): 1-9.

Kharrou MH, Salah R, Ahmed C, Benoit D, Vincent S, Michel L, Lahcen O, Lionel J. 2011. Water use efficiency and yield of winter wheat under efferent irrigation regimes in a semi-arid region. Agri Sciences 2(3): 273-82.

Rahman GA. 2009. Water use efficiency of wheat under drip irrigation systems. American-Eurasian J Agric \& Environ Sci. 5(5): 664-70.

Sharma, R. B. 2005. Optimizing root systemroot Zone relationship for efficient water use. Journal Indian Society of Soil Science 53(4): 537-57

\section{How to cite this article:}

Dabhi, M. S., A. S. Patel, K. J. Vihol, K. I. Patel, A. K. Patel and Patel, S. I. 2020. Efficient Water Management through Drip Irrigation in Wheat. Int.J.Curr.Microbiol.App.Sci. 9(08): 3646-3651. doi: https://doi.org/10.20546/ijcmas.2020.908.420 